\title{
Using Popular Culture as a Tool to Encourage Inclusive Discussions
}

\section{DRAFT PAPER}

\author{
Dr. Leanne Doherty, Associate Professor and Chair \\ Department of Political Science and International Relations \\ Simmons University ${ }^{\mathrm{i}}$
}

The Politics of American Pop Culture, an upper level political science elective, uses theories of culture, intersectionality, and institutions to help students ask and answer critical questions around power in the American Political system. Through an analysis of film, television (both reality and scripted), music, musical theater, and professional athletics, students are forced to analyze power dynamics around race, class, and gender - why do some groups work outside the formal political system through popular culture to change the system so it works to their advantage. This paper/discussion will define what we mean by popular culture today, how students are exposed to various works of popular culture, and how using this framework has created more engaging discussions around oppression, representation, and engagement. Finally, it will discuss how students elevate their own understanding of popular culture in the American political discourse.

Keywords: TLC 2020, The Inclusive Classroom, Popular Culture, Intersectionality 


\section{$\underline{\text { Introduction }}$}

In traditional political thought, the American political system typically can be navigated in one of two ways; through formal, institutional mechanisms (e.g. voting) or through 'informal' ways, such as protest. As a result, scholars often look at discussions of engagement through these two lenses and measure the effectiveness of these tools on democracy. If this dichotomy holds true, then where does culture, and for the purposes of this paper, popular culture fit in an analysis of political engagement in the United States? Do popular music, tv, film, athletics, and theater, for example, affect the way citizens engage with the American political system?

For numerous scholars in political science, sociology, cultural studies, and communication, the answer to these questions is a resounding yes (see Wright, 2019; Baumgartner and Morris 2014; Foy, 2009 Van Zoonen, 2005). Aspects of popular culture make information more relatable to multiple audiences, evolve with changes in how information is disseminated, and bring more people to the discussion (Street, Inthorn, and Scott, 2015). Popular culture can also bridge the gap between the formal mechanisms of American political engagement and those who feel that the system does not work for them (Watkins, 2006).

Bridging this gap is especially important in discussions of American politics and inclusion. Who is allowed to be at the table for political decision making, what questions are being asked, what policy arenas are identified as problems, all are influenced by the intersectional identities of those in political positions of power. The same holds true for those who decide what is high culture - what makes art "art" that you see in a museum, for example. The Politics of American Popular Culture, an upper level elective in Political Science, attempts to expose students to multiple modern aspects of popular culture not only to engage the class 
with theories of political science (e.g. participation, social movements, institutions) but to help them navigate difficult discussions around identity politics in the United States.

\section{Popular Culture and Intersectionality in the Classroom}

As The Politics of American Pop Culture has only Introduction to American Politics as a prerequisite, and because there have been numerous non-majors in the class (about half of 25 students that were registered both times I have taught the course), it was imperative that students work with the same definitions while also understanding that we are using theory for analysis in the class and not just watching a bunch of episodes of The Simpsons or Parks and Recreation.

When designing the class, I had the following learning goals in mind:

1. Encourage students to have more discussions around inclusion and politics. This could mean discussions of diversity and equity; it could also mean inclusion of different cultural texts that might be negatively perceived by those in power.

2. Navigate the discourse around youth disengagement with the formal political system with students currently in that demographic themselves.

Therefore, presentation of theoretical frameworks was the most important part of the first two weeks of class. In order to be able to analyze the 'fun' texts the course suggested would be present, the groundwork for the discussions was presented.

There are multiple ways that culture ${ }^{\mathrm{ii}}$ can be defined - a way of life for a group of people that connects them (e.g. holidays, language), a mode of behavior that is associated with a community during a period of time, or texts and practices whose function is to signify an era (e.g. music) (Williams, 1983, p. 87-91). John Storey elaborates on Williams' definitions of culture and more specifically, popular culture stating “...popular culture is simply culture widely 
favoured or well-liked by many people...it is the culture that is left over after we have decided what is high culture...it is mass-produced culture...” (Storey, 2018, p. 5-6). Needless to say, popular culture has a 'know it when you see it' kind of definition, which makes its membership fluid and temporal. For this class, I chose to focus on how popular culture links the public and private spheres and blurs lines of division that maybe be based on gender, race, class, and other forms of identity. Yes, it is entertainment for the masses, but that does not mean it should be considered unimportant. Williams (1974) also clarifies two other important facets of popular culture that are especially important for this class; that there is something authentic about the idea of popular culture because of its 'creation by the people' and that the popular culture product can be demonstrative of the struggle between subordinate and dominant groups in society during a certain period of time. These two points allow for the course to also focus on inclusiveness, or the lack thereof in American politics, through the theory of intersectionality.

Intersectionality is a theoretical lens that claims that one personal identity cannot explain all conditions of social and political life/self (Collins, 2013). In other words, the multiple identities that one can have that are differently affected by systems, policies, and institutions, for example and thus can affect one's relationship to power. Kimberle' Crenshaw first coined the term intersectionality in her 1989 paper "Demarginalizing the Intersection of Race and Sex: A Black Feminist Critique of Antidiscrimination Doctrine, Feminist Theory and Antiracist Politics" For this class, I asked students to think about intersectional theory as it relates to power, politics, and popular culture. Students reflect on interpersonal, disciplinary, cultural, structural, social context, and social justice aspects of power (Hancock, 2013) using intersectionality as an analytical tool to evaluate popular culture's relationship with American politics. 
These two theoretical frameworks set the stage for the rest of the class. In both explicit and implicit ways, this framing indicates that there will always be questions of who is missing? Whose voice is not being heard? What institutional mechanisms have been put in place in the American political and economic systems that make it difficult for all members to participate equally? The major difference from most political science classes is that we used modern popular culture texts to try to answer these questions.

\section{Methods of Fostering Inclusive Conversations}

\section{Discussion Questions}

Five times throughout the semester, students were asked to write 2-page papers to formal prompts in the syllabus. These prompts were to be completed before class, cite readings and other texts (e.g. songs, tv shows, memes, etc.) to answer the question, and analyze the relationship between the political system and popular culture. I have found that students feel more comfortable in critical classroom discussions if they are required to write about the topic first. For example, students were posed the following question during the topic of television:

Gender, race, and sexual orientation (amongst others) are prevalent themes in pop culture. Often, however, it is a "add and mix" type presentation - where characters are introduced without much substance. Describe at least one of these themes in television shows (drama, reality, sit-com, etc.) and how it is portrayed. What is the reason for the lack of progressive presentations of difference on television? Does it matter? 
Students drew from their own personal television watching experiences and started to notice patterns in certain television shows that supported the use of an intersectional framework. Some of the responses included thoughts such as:

- In the last several years there has been a rise in sitcoms that portray some sort of quirky, modern family dynamic, usually in the form of differences in race or family structure. These situations are rich ground for comedy, often providing material that would not be possible for a white family to experience (Van Zoonen, 2005). Instances of cultural differences and plays on stereotypes are the backbone of this new subgenre. The television show Modern Family exemplifies this pattern. The basic premise of the series relies on the differences and challenges the characters face as they deal with their various identities. Despite initially being praised for portraying diverse characters, in recent years Modern Family has been criticized for perpetuating negative stereotypes, specifically in regards to the Latina character "Gloria" and gay couple "Mitchell and Cam."

- Lesbian characters have... different stereotypes, but have the extra facet of being heavily sexualized. Their stereotypes are...extreme nature, showing butch lesbians with overemphasized “masculine” traits and interests, or using lipstick lesbians as the other extreme. ... when lesbians become the focus of a television show their stereotypical traits become exaggerated for the audience. The most well-known example of a lesbian focused television show is the L Word, which while it had similar advantages to shows like Glee in that it showed LGBT members in a positive and relatable light, it also emphasized stereotypes and was stylized so sexually that it was limited as a Showtime production. 
Both of these examples show students starting to explore ideas of race, class, gender, and sexual identity as they are portrayed in television. Intersectional theory had only recently been introduced to them; however, I was able to see that the majority of the students were starting to understand how one aspect of the American political system, capitalism, effects how characters with multiple identities are portrayed on tv. This led to a class discussion on the nature of privatized entertainment culture and who is control of it, whether it be writers, producers, or advertisers. Students also started to think about how this "mix and stir" theory of inclusion also was represented in elections, voting behavior theory, and social movement theory, even if those were not the specific theories being presented in class.

\section{Live Viewing of Short Television/Movie Clips}

Popular culture and its relationship to political satire was another major part of the course. Students were introduced to Horatian and Juvenalian forms of satire and its role in American political discourse. As described in Gray, et. al (2009, p.8-12), good satire can not only tell stories that those who are most affected cannot tell, it can engage civic culture by encouraging public discussion, and creates political efficacy for the masses. Movies and tv shows like The Simpsons, Dave, Family Guy, and Saturday Night Live, all had small clips that could be shown in class to discuss the uses of satire. So, how does good satire teach students to be aware that public policy making in the United States tends not to use an intersectional lens in the problem definition or implementation phase?

Really?!? With Seth and Amy was a long running skit on SNL which featured Seth Meyers and Amy Poehler, where they would question whatever group or person they felt was out of line with normal reasoning as they played news anchors on Weekend Update. On February 
18, 2012, Poehler returned to SNL after leaving for her own sitcom (Parks and Recreation) to join Meyers in a Really?!? discussion on a Congressional Hearing concerning birth control coverage under the Affordable Care Act. From the transcript of that segment intersectionality at play:

Seth Meyers: This week, the birth control debate came to the forefront again, after Congressman Daniel Eissmann called a hearing on President Obama's healthcare mandate, but failed to invite any women to join the panel. That brings us to a segment we like to call: "Really!?! with Seth and Amy".

Amy Poehler: Really? Really, Congress? You held a congressional committee on reproductive rights, and you did not invite any women? Really! That would be like not inviting any men to a congressional committee debating the Maxim Top 100! Really! Seth Meyers: Really! And, really — men HAVE to be smarter when they talk about birth control. This week, Foster Frees, the billionaire backer of Rick Santorum, joked that when he was young, women held an aspirin between their knees for birth control. Good one! But do you really want to start a discussion of health care with "When I was young...”? when you were young, people died of polio! I mean, really!

Amy Poehler: Really! Now, later in the week, Frees apologized for his comments. Well, we'd love to accept your apology, Foster, but you made a mistake... and now you're going to have to live with that mistake for the rest of your life! Really!

Through the use of satire, students were able to see that not only can popular culture like television be relevant, but can also raise issues of inclusion, bias, and intersectionality without naming it as such. If a key tenant of both popular culture and intersectionality is to include voices that may not otherwise be heard, this clip is a prime example of how something that is just 
"funny" becomes topical and important. Conversation about race, LGBTQ+, and gender health disparities, social inequities, and descriptive representation all resulted from showing this twominute video clip, as students were able to use the readings and their own connections to popular culture and current events to navigate these discussions.

\section{Documentaries}

The world of popular music has numerous documentaries that I use in this class that go beyond song lyrics and traditional analysis. What I have found is that many in the last 20 years have to do with the relationship between different subsets of popular music and the private radio marketplace. What is not necessarily advertised when these documentaries go public is that the conflicts they are portraying cross the lines between popular culture and formal pollical processes, with an intersectional analysis to boot.

Two such documentaries are "Shut up and Sing" and "The Hip Hop Fellow". "Shut Up and Sing". (2006, Kopple and Peck) recounts the controversy that the popular country and western group The Dixie Chicks faced when their lead singer criticized at the time President George W. Bush while touring in Europe in 2003. It explores issues of gender and capitalism in the very hyper masculinized world of popular music. Questions around what are the proper roles of celebrities in the American political process are constantly debated in modern democratic theory (see Wright, 2019), however, those of us who study gender and politics are hyper aware that these roles are scrutinized even more when identity politics are included in the discussion. Documentaries like this become the text for the students - they relate theories of culture and intersectionality on not only the documentary content but also on those who directed it, where it 
was distributed, what was the timeline of the controversy and why, etc. all the while exploring their own biases within music culture.

“The Hip-Hop Fellow" (Price, 2014), a documentary about Grammy-award winning music producer $9^{\text {th }}$ Wonder's time as a WEB DuBois fellow at Harvard, takes the discussion of bias, popular culture, and politics to the Academy. Within the piece, not only does $9^{\text {th }}$ Wonder navigate the historical roots of hip hop as a part of the post-Civil Rights movement, he navigates the cultural biases that come with being an academic fellow at Harvard. Questions such as can popular music have a place in academic discussions, what are the social and political rankings of the various types of hip hop, and what does this mean for political discourse all came to light with the viewing of this particular documentary.

Both films also pushed students to discuss issues of what it means to dissent in modern America. When we reflected back on Williams' theory of popular culture being a way for oppressed groups to navigate the power dynamic with their oppressor, students correctly pushed back, asking if an artist (in this case) could truly call for change when their intersectional identities add to the oppression they face with in the American political system. Or does that artist have to become part of the high culture, no matter what the medium, in order to make systemic change.

I present these three methods as examples of how to support more inclusive conversations around American politics using popular culture texts. This list is far from exhaustive; however, I do feel they give examples of assignments and pedagogical tactics that faculty can use to bring more diverse opinions to the table.

\section{$\underline{\text { Discussion/Reflection }}$}


It would be easy to say this course was a success based on student evaluations. Overall, the course received a 4.7 and 4.65 (out of 5) for student satisfaction and students overwhelming said they thought the course was well organized and engaging. However, I wanted to use this opportunity to review my stated goals from the beginning of the class and see if there were any outcomes I could expand upon in my next session of this class, which will be in Fall 2020. Goal 1 - Encourage students to have more discussions around inclusion and politics. This could mean discussions of diversity and equity; it could also mean inclusion of different cultural texts that might be negatively perceived by those in power.

I believe this goal was accomplished, even more than I expected. Students in their written comments on the course said things like:

- This course made me think differently about power and who gets to decide what is popular

- I was exposed to materials I never would have looked at on my own

- It was great to see the music I liked (both hip hop and country music were named in similar comments like this) in one of my political science classes that was not used as a joke or a put down.

Goal \#2 - Navigate the discourse around youth disengagement with the formal political system with students currently in that demographic themselves.

Nothing from the student evaluation comments or anecdotal comments indicated that there was any change in engagement. In order to measure this goal in the fall, I want to craft a pre/post-test around measures of engagement and see if the results change after students take the class. If they do, this might be an opportunity to expand civic and political knowledge in our 
classrooms. If not, I might have to think about this specific goal being too much to ask for in a class that many students enroll in because "it sounds fun."

A couple of take aways from teaching this course - it is a tremendous amount of work. I fancy myself in tune to multiple issues of American popular culture, but my GenX lifestyle is getting in the way of staying in front of every meme, GIF, Reddit Stream, Instagram post and TicToc that goes live. Popular culture has adapted to the 24-hour information cycle where the majority of traditional students live. Often, I would come into class and students would ask me about some YouTube influencer who said such and such and I would honestly say I had no idea what they are talking about.

With this confession out of the way, I will be looking into theories of social media and inclusion for the next iteration of this class. Studies around "Black Twitter" and other social movements within Twitter and Instagram (e.g. Parkland students and Gun Control) have started discussions around democratic activism through social media.

Second, I would like to expand the popular culture examples in the course to include more Latinx, Asian, and indigenous directors, actors, and topics. My assumption is that the general themes of intersectionality and popular culture will stay the same including more targeted works by these identity groups, however, questions of access, citizenship, and engagement may be very different in these pieces.

Third, teaching this course has changed my scope of personal research. I have been convinced that popular culture is an underutilized tool in political efficacy, especially for underrepresented groups. Once again, the classroom is perfect environment to test out one's own research questions, as there is no tougher reviewer than our students. 


\section{Works Cited}

Baumgartner, Jody, Jonathan S. Morris, and S. Robert Lichter. (2014). Politics is a Joke! How TV Comedians are Remaking Political Life. New York: Routledge.

Collins, Patricia. (2015). “Intersectionality’s Definitional Dilemmas.” In Annual Review of Sociology, 41(1), 1-20.

- (1999). Black Feminist Thought: Knowledge, Consciousness and the Politics of Empowerment. New York: Routledge.

Crenshaw, Kimberle'. (1989). "Demarginalizing the Intersection of Race and Sex: A Black Feminist Critique of Antidiscrimination Doctrine, Feminist Theory and Antiracist Politics," University of Chicago Legal Forum: Article 8.

Foy, Joseph J., ed. (2009). Homer Simpson Goes to Washington: American Politics Through Popular Culture. University of Kentucky Press: Lexington, KY.

Gray, Jonathan, Jeffery Jones, and Ethan Thompson. (2009) Satire TV: Politics and Comedy in the Post-Network Era. NYU Press: New York, p. 8-12.

Hancock, Ange-Marie. (2013) "Empirical Intersectionality: A Tale of Two Approaches," 3 U.C. Irvine L. Rev. 259.

Kopple, Barbara and Cecilla Peck. 2006. Dixie Chicks: Shut Up and Sing. The Weinstein Company.

Price, Kenneth. 2014. The Hip Hop Fellow. Price Films.

SNL Transcripts Tonight, https://snltranscripts.jt.org/11/11oupdate.phtml, (accessed January 15, 2020).

Street, John, Sanna Inthorn, and Martin Scott. (2016). From Entertainment to Citizenship: Politics and Popular Culture. Manchester: Manchester University Press.

Storey, John. (2018). Cultural Theory and Popular Culture: An Introduction. $8^{\text {th }}$ edition. New York: Routledge.

van Zoonen, Lisebet. (2005). Entertaining the Citizen: When Politics and Popular Culture Converge. New York: Rowman \& Littlefield.

Watkins, S. Craig (2006). Hip Hop Matters: Politics, Pop Culture, and the Struggle for the Soul of a Movement. Boston: Beacon Press.

Williams, Raymond. (1983). Keywords: A Vocabulary of Culture and Society. New York: Oxford University Press. 
-- (1974). “On High and Popular Culture.” The New Republic. November 22.

Wright, Lauren. (2019) Star Power: American Democracy in the Age of the Celebrity Candidate. New York: Taylor and Francis.

\footnotetext{
' Simmons University is a women-centered undergraduate institution with graduate programs in the health sciences, library sciences, public health, social work, and the liberal arts located in Boston, Massachusetts.

ii Merriam-Webster named "culture" its word of the year in 2014. The word itself has become associated with groups of thought as well as the examples listed above. For example, "startup culture" or "rape culture". iii https://www.nbc.com/saturday-night-live/video/really-with-seth-and-amy-birth-control/n13402
} 